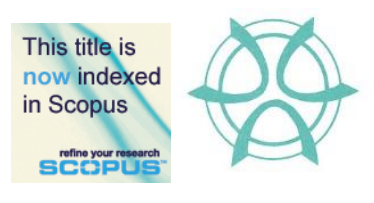

PLANNING MALAYSIA:

Journal of the Malaysian Institute of Planners

VOLUME 16 ISSUE 2 (2018), Page 73 - 82

\title{
THE BASIC CRITERIA FOR THE PROVISION OF AFFORDABLE HOUSING IN MELAKA
}

\author{
Mariana Mohamed Osman', Muhammad Adib Ramlee², Syakir Amir Ab \\ $\operatorname{Rahman}^{3} \&$ Mansor Ibrahim ${ }^{4}$ \\ ${ }^{1,2,3,4}$ Kulliyyah of Architecture and Environmental Design, \\ INTERNATIONAL ISLAMIC UNIVERSITY MALAYSIA
}

\begin{abstract}
The aim of this paper is to examine the criteria in the selection of the houses by the homebuyers in Melaka. The case study area was selected from Melaka in response to the report produced by Khazanah Research Institutes (KRI) in 2015 that claims Melaka is the most affordable state in Malaysia. This study applies the quantitative approach. The Yamane Taro 1976 sampling formula was used and 400 samples were selected. Three types of analysis techniques was utilized namely descriptive analysis, Pearson correlation and Relative Importance Index (RII). The study found that the three districts in Melaka were at affordable range for 2012 and 2014 and the income level of the household in Melaka was within the average income of Malaysia. Finally, it is anticipated that the study would give a clear picture on what are main criteria of better housing provision in Malaysia.
\end{abstract}

Keywords: housing price, affordable house, Melaka. 
Mariana Mohamed Osman, Muhammad Adib Ramlee, Syakir Amir Ab Rahman \& Mansor Ibrahim

The Basic Criteria for The Provision of Affordable Housing in Melaka

\section{INTRODUCTION}

Owning a home for shelter and comfort is considered by many as a life goal and a measure of personal success (Hashim, 2010). However, the price of houses is increasing and houses become unaffordable to own. In Malaysia, the same situation occurs where house price is surging upwards, proportionately to income. Land scarcity and economic growth have often been cited as the factors that drive house price up to the point that it becomes unaffordable to the majority of Malaysian public (Hashim, 2010). As Malaysia aspires to be a developed nation with high-income economy by 2020 , the housing industry needs to be adaptive and responsive to demand for special groups, especially the medium and low income earners. Cagamas (2013) proposes that the Government must take appropriate measures to ensure access to quality and affordable housing is for all. Cagamas (2013) also notes that as public purchasing power reduces, housing affordability gap has widened even further. However, Ong and Chang (2013) argues that the determining factors on the ability to purchase a property are not dependable solely on income but also by the high house price and the mortgage interest rate. Making houses affordable, especially to the lower income group is critical for poverty reduction, institution building, good governance at the local and national levels, and conflict prevention (Sohaimi, Abdullah, \& Shuid, 2017). The objective of this paper is to provide an overview of the affordable housing scenario in Melaka and to determine the housing affordability index for each district in Melaka. It is hoped that the findings from this paper would contribute in making housing more affordable to the Malaysian public.

\section{LITERATURE REVIEW}

Housing is one of the most vital investments that is made by individuals, as housing influence the social interactions and represent socioeconomic status. Tan (2013), and Glaeser and Sacerdote (2000) assert that high housing ownership creates a better motivation for homeowners to enhance the quality of the community and develop homeowners' connection with the neighbourhood. Hence, proper housing unit is one of the prominent requirements to ensure the needs of house as shelters and preferences in selecting home are being fulfilled. Besides that, the housing prices are influenced by demographic factors such as level of income of the individuals, the stock price, cost of capital and population expansion (Osman, Ramlee et al., 2017). The higher the demand it incurred the more houses need to be developed with the limitation resources such as land, increase of construction materials and many others. In addition, the housing location especially in the urban and attraction areas contribute to ridiculously increasing house prices. Eventually, houses were unaffordable for public to own. The increase of property value in most developed and developing countries have been alarming issues that need to be addressed and revised. Especially in 
Malaysia, the increase of property value specifically in the urban centers lead inability of housing ownership.

There are several other criteria considered by home buyers in selecting their dream houses. The criteria for the provision of the affordable housing are not solely specific on housing designation but it goes beyond the physical design of the house. Such as the provision of better infrastructures and facilities that contribute to mobility of the residents. Therefore, the main idea of this paper is to provide overview by examining and identifying the basic criteria in the provision of affordable housing in Melaka. The state of Melaka is considered as the most affordable state in Malaysia with median multiple index of 3.0 (KRI, 2015; Osman, Rabe, Abdullah, Rosli, \& Zainudin, 2017). This study identifies the criteria to attract people to buy properties. The criteria of housing selection relate to house prices, housing location and surrounding facilities provided.

\section{OBJECTIVE OF THE STUDY}

a) To determine the basic elements criteria in providing good affordable housing

b) To study the factors that contribute to housing preferences

c) To provide recommendations and solutions

\section{METHODOLOGY}

The method used in the study was quantitative approach, which the primary source of data was from the questionnaire surveys. The criteria of samples selection include Malaysian, having a stable income and a tenant. The method of sampling was random sampling methods. The calculation of 400 samples was calculated based on Yamane Taro's (1967), and the formula is as shown below:

$$
* n=\frac{N}{1+N(e)^{2}}
$$

where:

$\mathrm{n}=$ Sample Size

$\mathrm{N}=$ Population Size

$\mathrm{e}=$ Level of precision or sampling of error, which is $\pm 5 \%$

In addition, the random sampling methods was used and the type of analysis used such as descriptive analysis, Pearson Correlation analysis and Relative Importance Index (RII). 
Mariana Mohamed Osman, Muhammad Adib Ramlee, Syakir Amir Ab Rahman \& Mansor Ibrahim The Basic Criteria for The Provision of Affordable Housing in Melaka

\section{FINDINGS AND ANALYSIS}

\section{Socio Demography Profile}

Table 1.0 illustrates the socio demography of the respondents in Melaka. There were a few basic of socio demography components that were asked and the components could also be the contributing factors for the house buyers. Most of the respondents were between 21 and 40 years old. More than $80 \%$ of the respondents were renting, did not own a property and wanted to purchase house. $50 \%$ of the respondents were between 21 and 30 years old. The age factors may contribute to the ability of the respondents to buy a property.

Table 1: The socio demography of the respondents in Melaka

\begin{tabular}{|c|c|c|}
\hline Profile & $\begin{array}{c}\text { Number of } \\
\text { Respondents }\end{array}$ & Percentage \\
\hline \multicolumn{3}{|l|}{ Age Range } \\
\hline 20 and Below & 14 & 3.5 \\
\hline $21-30$ & 200 & 50.0 \\
\hline $31-40$ & 130 & 32.5 \\
\hline $41-50$ & 41 & $10 . \overline{25}$ \\
\hline $51-60$ & 15 & 3.75 \\
\hline Total & 400 & 100.0 \\
\hline \multicolumn{3}{|l|}{ Level of education } \\
\hline Primary School & 2 & 0.5 \\
\hline Secondary School & 107 & 26.75 \\
\hline STPM/Certs/Diploma & 145 & 36.25 \\
\hline Degree & 119 & 29.75 \\
\hline Master & 23 & 5.75 \\
\hline $\mathrm{PhD}$ & 4 & 1.0 \\
\hline Total & 400 & 100.0 \\
\hline \multicolumn{3}{|l|}{ Household Number } \\
\hline $1-2$ & 51 & 12.75 \\
\hline $3-4$ & 189 & 42.75 \\
\hline $5-6$ & 126 & 31.5 \\
\hline $7-8$ & 31 & 7.75 \\
\hline $9-10$ & 3 & 0.75 \\
\hline Total & 400 & 100.0 \\
\hline \multicolumn{3}{|l|}{ Type of Profession } \\
\hline Executive/ Professional & 120 & 30.0 \\
\hline Administration/Management & 112 & 28 \\
\hline Technical Assistant & 32 & 8 \\
\hline Retails & 51 & 12.7 \\
\hline Non-Technical & 40 & 10.0 \\
\hline
\end{tabular}


PLANNING MALAYSIA

Journal of the Malaysia Institute of Planners (2018)

\begin{tabular}{l|c|c}
\hline $\begin{array}{l}\text { Entrepreneur/Work } \\
\text { Independently }\end{array}$ & 45 & 11.3 \\
\hline Total & 400 & 100.0 \\
\hline Income Range & \multicolumn{2}{|l}{} \\
\hline 2,000 and Below & 45 & 11.25 \\
\hline $2,001-4,000$ & 105 & 26.25 \\
\hline $4,001-6,000$ & 90 & 22.5 \\
\hline $6,001-8,000$ & 69 & 17.25 \\
\hline $8,001-10,000$ & 54 & 13.5 \\
\hline 10,001 and Above & 37 & 9.25 \\
\hline Total & 400 & 100.0 \\
\hline
\end{tabular}

The level of education influence behaviour of homebuyers. $73 \%$ of the respondents had underwent tertiary education and $27 \%$ of the respondents had secondary education level. $36.25 \%$ of the respondents had STPM/certificates and diploma qualification and $30 \%$ of the respondents held Degrees qualifications. Education levels influence the deliberation and preferences of the individuals' in house selections.

Most respondents (75\%) had 3 to 6 household size. Household size determines the criteria or preferences of the homebuyers. Such criteria include housing size, housing type and housing comfort.

$58 \%$ of the respondents worked as executive or professionals and management. $30 \%$ of the respondents were holding position as an executive or professional, while $28 \%$ of them from management professions.

$48 \%$ of the respondents earned between RM 2,000 and RM 6,000 monthly. Majority of the respondents (26\%) earned between RM 2,001 and 4,000 per month. The mean income of the respondents was RM 5,904 and the median was RM 5,500 monthly. The income range influence housing selection criterion. The higher the income, the bigger the chances that respondents had to own houses, hence the more criteria would be considered, such as comfort, better surveillance and privacy.

\section{Perceptions and Information on the Element Housing Criteria}

Table 2 shows the range of affordable housing price based on demographic and socioeconomic background. $90 \%$ of the respondents stated that the affordable housing price was RM 300,000 and below. Additionally, the mean affordable housing price was RM 211,070 and the median was RM 165,000. Below is the correlation between household income and housing price.

Table 2: Affordable house price

\begin{tabular}{ccc}
\hline Price Range & Frequency & Percentage \\
\hline 300,000 and below & 359 & 89.75 \\
$301,000-600,000$ & 40 & 10.0 \\
\hline
\end{tabular}


Mariana Mohamed Osman, Muhammad Adib Ramlee, Syakir Amir Ab Rahman \& Mansor Ibrahim The Basic Criteria for The Provision of Affordable Housing in Melaka

\begin{tabular}{ccc}
\hline 700,000 and above & 1 & 0.25 \\
Total & 400 & 100.0 \\
Mean & Median & Mode \\
RM 211,070 & RM 165.000 & RM 200,000 \\
\hline
\end{tabular}

There was a statistically significant and moderate positive correlation between household income and housing price $(r=.0428,=<0.05)$ (see Table 3 ). The result indicated that the higher the household income, the higher the housing price affordable to the respondents.

Table 3: Pearson correlation between income and price range

\begin{tabular}{|ll|c|c|}
\hline & $\begin{array}{c}\text { household } \\
\text { income }\end{array}$ & $\begin{array}{c}\text { housing } \\
\text { price }\end{array}$ \\
\hline household income & Pearson Correlation & 1 & $.428^{* *}$ \\
& Sig. (2-tailed) & & .000 \\
& $\mathrm{~N}$ & 400 & 400 \\
\hline housing price & Pearson Correlation & $.428^{* *}$ & 1 \\
& Sig. (2-tailed) & .000 & \\
& $\mathrm{~N}$ & 400 & 400 \\
\hline
\end{tabular}

**. Correlation is significant at the 0.01 level (2-tailed).

\section{Important Criteria in the Provision of Affordable House in Melaka}

Table 4.0 shows the criteria in the provision of affordable housing. There were several housing criteria that were inquired and the data were analysed using relative importance index (RII) in SPSS. The purpose of the analysis was to measure the priority of the housing criteria according to the respondents. The highest RII score was House Price with RII of 0.90. Housing price was the main concern not only in Melaka but in Malaysia. Housing price were increasingly unbearable and unaffordable especially in major city areas.

The second highest RII score was Security Level with RII of 0.89 and the third highest RII score was Access to Public Facilities such school, clinic and many others. These facilities were essential to better facilitate homeowners to access better quality of life. On the other hand, the lowest RII score was Number of Bedrooms and Bathrooms and House Design with RII score of 0.82 and 0.80 respectively. In conclusion, if the houses was affordable and equipped with basic facilities and amenities, the housing designs would not be a major concern.

Table 4: Important criteria in the provision of affordable house

\begin{tabular}{lccc}
\hline Statement & $\begin{array}{c}\text { Total } \\
\text { Weightage }\end{array}$ & RII & Rank \\
\hline Type of House & 3323 & 0.84 & 9 \\
House Price & 3594 & 0.90 & 1 \\
\hline
\end{tabular}


PLANNING MALAYSIA

Journal of the Malaysia Institute of Planners (2018)

\begin{tabular}{lccc}
\hline Location of the house & 3485 & 0.87 & 5 \\
House design & 3201 & 0.80 & 11 \\
Number of Bedrooms and Bathrooms & 3289 & 0.82 & 10 \\
The Quality of Construction & 3457 & 0.86 & 6 \\
Total floor area & 3392 & 0.85 & 7 \\
Security Level & 3571 & 0.89 & 2 \\
Access to public Facilities & 3518 & 0.88 & 3 \\
Distance from working area & 3505 & 0.88 & 4 \\
Access to public transportation & 3371 & 0.84 & 8 \\
\hline
\end{tabular}

\section{Level of Satisfaction with the Current House}

Table 5 shows the level of satisfaction of the current house. Types of House had the highest weightage score of 2993 or 0.74 RII score. Secondly, Access towards Public Facilities had 0.74 RII score. Based on the verbal interviews, most respondents mentioned that the accessibility towards public facilities were short driving distances. The respondents were also satisfied with the distance to work. However, there were several issues to be addressed such as the Housing Price as well as the Accessibility of Public Transportation connecting to the neighbourhood areas. The Accessibility of Public Transportation was least satisfied with the RII score of 0.65 . Hence improvement should be made on the accessibility to public transportation.

Table 5: Level of satisfaction with current house

\begin{tabular}{lccc}
\hline Statement & $\begin{array}{c}\text { Total } \\
\text { Weightage }\end{array}$ & RII & Rank \\
\hline Type of house & 2993 & 0.75 & 1 \\
Access to public transportation & 2602 & 0.65 & 12 \\
House price & 2782 & 0.70 & 11 \\
Security Level & 2855 & 0.71 & 7 \\
Location of the house & 2899 & 0.72 & 6 \\
Total floor area & 2790 & 0.70 & 10 \\
House design & 2796 & 0.70 & 9 \\
Number of bedrooms and bathrooms & 2886 & 0.72 & 5 \\
Access to public facilities & 2968 & 0.74 & 2 \\
quality of construction materials & 2837 & 0.71 & 8 \\
Distance from work & 2917 & 0.73 & 4 \\
Overall satisfaction of current house & 2953 & 0.74 & 3 \\
\hline
\end{tabular}


Mariana Mohamed Osman, Muhammad Adib Ramlee, Syakir Amir Ab Rahman \& Mansor Ibrahim

The Basic Criteria for The Provision of Affordable Housing in Melaka

\section{Level of Satisfaction with Public Facilities and Infrastructure}

Table 6 indicates the level of satisfaction on public facilities and infrastructure of current house. The highest weightage scored is water and electricity with 3053 or RII score of 0.76 . The religious facilities and education facilities also shared the same RII scores which was 0.76 , but differed by the weightage scores of 3025 and 3021 respectively. In addition, the drainage system and the health facilities also shared the same RII of 0.75 but the drainage total weightage was greater compared to health facilities. The sport and recreational facilities had the least score with RII score of 0.72 . In summary, the respondents were satisfied with the overall basic facilities provided in most neighbourhood areas.

Table 6: Level of satisfaction of the public facilities and infrastructure

\begin{tabular}{lccc}
\hline Statement & $\begin{array}{c}\text { Total } \\
\text { Weightage }\end{array}$ & RII & Rank \\
\hline Circulation system & 2971 & 0.74 & 6 \\
Water and electricity & 3053 & 0.76 & 1 \\
Drainage system & 2984 & 0.75 & 4 \\
Sewerage system & 2948 & 0.74 & 9 \\
Garbage disposal system & 2887 & 0.72 & 11 \\
Clinic and health facilities & 2982 & 0.75 & 5 \\
Commercial Facilities & 2958 & 0.74 & 7 \\
Playground and open spaces & 2901 & 0.73 & 10 \\
Sports and recreational facilities & 2873 & 0.72 & 12 \\
Religious facilities & 3025 & 0.76 & 2 \\
Education facilities & 3021 & 0.76 & 3 \\
Parking area & 2959 & 0.74 & 8 \\
\hline
\end{tabular}

\section{DISCUSSION AND CONCLUSION}

The selection of housing criteria play a vital role especially to the first time homebuyers. The buyers were looking into houses that were decent to live, accommodate all the basic facilities, amenities and infrastructures. This study examine the important housing criteria based on respondents' preferences and satisfaction level on the current rental houses.

In order to encourage housing ownership, it is imperative to identify the determinants that attract individuals in buying a property (Tan, 2015). The housing price is closely related to income, education, household size and education level. It is anticipated that the suggestions made would help to minimize the current housing issues. According to the respondents, the main problem was the housing price. Housing prices were too high and were beyond respondents' ability to afford especially for those in the low and middle income groups. The housing schemes that were provided by the government were good enough to increase the number of housing ownership, yet the schemes still need to be regularly supervised. 
PLANNING MALAYSIA

Journal of the Malaysia Institute of Planners (2018)

Additionally, there should be enhancement of housing policies and regulations to be more pro poor. By increasing the construction of affordable housing and improving housing cost-effective design, housing prices would be more reasonable. Housing features could also be improved by upgrading facilities and amenities within the neighbourhood.

Affordable housing financing should be more attractive and reliable for all especially for the low income earners. The low income earners have restriction of income resources. The policy or programs that are going to improvised are anticipated to reduce the cost of homeownership through down payment and mortgage income payment. The government is urged to promote the increase in the availability of home financing by enabling the EPF fund to be more accessible to use for down payment and housing mortgage payment. The EPF process system should be simplified and integrated into all related agencies as it will ease process of application and submission of documents.

The study also shows most respondents were satisfied with the current condition of their houses. Yet, improvisation should be conducted from time to time in order to ensure that the people were happy with their living environment. Apart from that, the provision of parking spaces should also be revised especially in high-rise development. Multiple parking spaces for high rise buildings should be provided not only in high cost housing development but also for middle and low cost housing development. The accessibility towards public transportation should also be a concern by the housing developers and respective authorities. Access to public transport influence the value and the attractiveness of housing development.

In conclusion, more proactive approaches and housing strategies need to be executed to increase housing ownerships and better living environment are achieved.

\section{REFFERENCES}

Cagamas (2013). Housing the nation: Policies, issues and prospect. Kuala Lumpur: Author.

Glaeser, E. L., \& Sacerdote, B. (2000). The social consequences of housing economics. Journal of Housing Economics, 9(1/2), 1-23.

Hashim, Z. A. (2010). House price and affordability in housing in Malaysia AKADEMIKA, 78 (Jan-April), 37-46.

Khazanah Research Institute (2015). Making housing affordable. Kuala Lumpur: Author.

Ong, T. S., \& Chang, Y. S. (2013). Macroeconomic determinants of Malaysian housing market. Journal of Human and Social Science Research, 1(2), 119-127.

Osman, M. M., Rabe, N. S., Abdullah, M. F., Rosli, N. F., \& Zainudin, F. E. (2017). Housing affordability in the state of Melaka. Planning Malaysia, 15(1), 255260. 
Mariana Mohamed Osman, Muhammad Adib Ramlee, Syakir Amir Ab Rahman \& Mansor Ibrahim

The Basic Criteria for The Provision of Affordable Housing in Melaka

Osman, M. M., Ramlee, M. A., Samsudin, N., Rabe, N. S., Abdullah, M. F., \& Khalid, N. (2017). Housing affordability in the state of Johor. Planning Malaysia, 15(1), 347-356.

Sohaimi, N. S., Abdullah, A., \& Shuid, S. (2017). Housing affordability and pathway among Malaysian young professional in Greater Kuala Lumpur. International Journal of Academic Research in Business and Social Science, 7(2), 653-665.

Tan, T. H. (2013). Homeownership schemes in Malaysia for first homebuyers. Habitat International, 36(1), 108-116.

Yamane, T. (1967). Statistics: An introductory analysis (2nd Edition). New York: Harper and Row. 